\title{
MINIMUM LEVELS OF SERVICES OF GENERAL INTEREST - WHAT FUNDAMENTAL RIGHTS DO INDIVIDUALS AND ENTERPRISES HAVE?1
}

\author{
HELENE LITTKE \\ Royal Institute of Technology (KTH) \\ Division of Urban and Regional Studies \\ Drottning Kristinas väg 30 \\ 10044 Stockholm, Sweden \\ helene.littke@abe.kth.se \\ DANIEL RAUHUT \\ University West \\ Dept. of Social and Behavioural Studies \\ Gustava Melins gata 2 \\ 46186 Trollhättan, Sweden \\ daniel.rauhut@hv.se
}

\begin{abstract}
The European Union is currently experiencing a period of significant upheaval. The financial crisis, structural changes in the economy and population decline in many regions combine to make a difficult situation even worse in respect of SGI. To mitigate these problems EU policy on economic, social and territorial cohesion aims to remove regional differences and to otherwise affect policies to ensure the right to the same service status regardless of localisation. This paper aims to discuss what a minimum level of SGI means to individuals and enterprises. The key EU policy documents offer no guidance in terms of defining what a minimum level of SGI is, for either individuals or enterprises. It is up to the Member States to define the thresholds; national policies, traditions and moral values thereby creating a vague and heterogeneous notion of what constitutes a minimum level of SGI provision.
\end{abstract}

Key words: accessibility, public goods, services of general interest, rights theory, allocation

\section{INTRODUTION}

The European Union is currently experiencing a period of significant upheaval. Developments like new technologies, changing populations and economic instability necessarily affect policy options, regulations and requirements and underpin the need to consider the evolution of kinds of services that are now really essential. These ongoing changes have to some extent helped shape the development

1 This paper is part of the applied research project Indicators and Perspectives for Services of General Interest in Territorial Cohesion and Development (SeGI), led by the Royal Institute of Technology (KTH), Sweden. It has been financed by the ESPON 2013 Programme and this financial support is gratefully acknowledged. Texts, maps and conclusions stemming from research projects under the ESPON programme presented in this report do not necessarily reflect the opinion of the ESPON Monitoring Committee. (C) ESPON, 2013. 
of policies to strengthen the European economy and foster greater cohesion, a crucial element of this political response being the notion that competitiveness can best be increased through the creation of a knowledge-based economy.

In a market-driven economy questions of general supply in all geographical locations become an important issue as profitability may be low or insufficient in disadvantaged and/or sparsely populated areas. The efficiency and quality of SGI is essential for competiveness and cohesion of the society as well as for overcoming social exclusion. The notion of spatial dimensions also has a significant impact on the provision of Services of General Interest (SGI) provision as the perception of equitable supply is a fundamental tenet of a fair and democratic society. Territorial cohesion as a concept signifies the intent to remove regional differences and to seek to affect policies to the extent that all EU citizens' rights to the same service status are secured, regardless of localisation (European Union 2011).

Services of General Interest (SGI) are regarded, across Europe, as key societal components and as potentially providing a basis for a future 'European' society. Their role is important, for instance, in relation to the quality of life experienced by all citizens; they are also vital economic drivers and influence the production of goods and services. SGI include network services, such as telecommunications, postal services and energy as well as social services, such as child care, and also essential societal functions, such as waste management. As these services are important for the smooth running of everyday life they are necessarily connected with the rights of citizens in relation to the obligations of the state, both nationally and within the EU. Current EU legislation divides governance responsibility between the Community and the Member States, with the latter given the responsibility to define and organise Services of General Interest. The importance of the functioning of such services has, however, triggered a debate on the EU level over the need for a harmonised framework and regulations in respect of SGI. Currently, only the big network services have sector specific legislation, e.g. transport, electricity, ICT and telecoms. Services of general interest were first officially mentioned in 1996 (Foss 2011:12). The Green Paper of 2003 and the following White Paper of 2004 have raised further questions regarding the definitions, categorisations and common targets in respect of these services.

Services of General Interest are of crucial importance for everybody, both citizens and enterprises, which in many situations share the same needs. Functioning labour markets, affordable telecommunications, a constant flow of water from the tap are all among the mechanisms that make our society work. In some situations, however, the usage of services of general interest differs between citizens and enterprises, and in some areas the user rights differ, for example producers are responsible for handling their own waste, while citizens have the right to a functioning waste management system (European Union 2012).

This paper aims to discuss the notion of minimum levels of SGI and who has the right to SGI. To do this, many concepts must be examined. What is a Service of General Interest? What do we mean by rights in this context? Territorial cohesion is one of three cohesion goals adopted by the European Union, and it affects all policy areas. But as SGI is a wide and constantly evolving concept, linkages can be found to all policy areas and all parts of society. A central aspect of this paper is thus to gauge the extent to which individuals and businesses really expect the same access to services, regardless of their location? The study proposes three questions that need to be answered: (1) How are the rights to SGI defined in the key EU policy documents? (2) Is a differentiation made between individuals and enterprises in terms of their access to SGI as a right? (3) Is the issue of minimum levels of service provision actively discussed? To answer these questions a number of key EU policy documents are analysed. 
In the discussion on minimum levels, it is impossible to determine the quantitative levels of services, at the EU level, that would fulfil the requirements of universal access, affordability transparency, quality of service and user, and consumer protection (European Commission 2003:15) for all nations and regions in the Union, simply because of the heterogeneity of the territories themselves. In response, this paper seeks to specifically raise these aspects in order to better examine the connections between service access, service provision and territorial policies.

A brief introduction to some of the basic localisation theories is used to support the discussion on territorial cohesion in policy making and universal access to SGI. Even though the basic components of theories differ from the concept of SGI, they are, nevertheless, useful in that they provide a conceptual understanding of spatial patterns necessary for the analysis of distribution in relation to territorial cohesion. The theoretical chapter also contains some references to the theory rights; this introduction should not be seen as an exhaustive discussion of rights and Services of General Interest but rather as simply a way of establishing the connection between localisation, territorial cohesion, ideology, needs, and rights.

\section{KEY CONCEPTS}

\section{SERVICES OF GENERAL INTEREST - SGI}

The concept of SGI is an evolving one, based on the prevailing political and moral values in various Member States. The notions of public services, basic services and universal services are related, and a precise wording can be an important rhetorical tool in deciding upon the criteria for service performance. The term refers to a service that is "subject to specific public service obligations by virtue of a general interest criterion" (European Commission 2004:22) and its historical background can be derived from the medieval notion of common callings that refers to a person, organisation or business that is subject to special liabilities and duties. The services that have been seen as goods, however, vary over time. In the 14th century smiths and innkeepers were essential to provide security for travellers and were, therefore, a common calling, today both these services are of a strictly private and commercial nature (Van de Walle, 2008:11-12).

The concept of SGI itself is not actually defined in the Lisbon Treaty, being commonly derived from the term "Service of General Economic Interest" (SGEI), but it is mentioned in the protocol of Services of General Interest, annexed to the Lisbon Treaty in October 2007 and introducing the term into the EU primary legislation (European Commission 2007:9). The difference between the terms SGI and SGEI is that SGI also covers non-economic sectors classed by the authorities as subject to public service obligations (European Commission 2003:6-7).

In the Green Paper on Services of General Interest different types of SGI are discussed and categorised, and three types of services are identified, based on their different needs and roles in respect of the EU action as well as that of Member States (European Commission 2003:10). (1) The first typology is network industry services such as telecommunications, postal services, electricity, gas and transport. These services have, at least since the 1980s, been subjects to gradual liberalisation while the Community has, over time, developed a framework concerning public service obligations and consumer and user rights. Features common to these services include their dispersion over national borders and their importance for other services and societal and economic development as well as for cohesion more generally. (2) The second type of service is of economic interest but of a more site-specific nature. Such services includes waste management, water supply and public service broadcasting which are not regulated at the Community level but are handed by national level internal 
markets, although they can affect trade between Member States and are subject to sector specific Community regulation, e.g. environmental legislation. (3) The last type of services is non-economic in character, with no trade effects, and is not regulated by the Community other than in relation to basic principles such as non-discrimination (European Commission 2003:10).

This distinction between economic and non-economic services is crucial for the application of Treaty rules. The principles of non-discrimination and the free movement of persons are applicable to all services, while only economic services are affected by the freedom to provide services, the right of establishment, the competition, and 'state aid' rules of the Treaty. An activity is regarded as being of an economic nature if it encompasses offering of goods and services on a market; this also applies to connecting upstream markets to services of a non-economic nature (European Commission 2003:14).

To acknowledge the importance of social services the term Social Services of General Interest (SSGI) was introduced as a sub-category of SGI. The Community law does not differentiate between these two terms but the introduction of the term SSGI in policy documents is seen as an important demonstration of its importance (European Commission 2006:4). SSGI include statutory and complementary social security schemes, designed to alleviate the risks faced by individuals and linked for instance to health, ageing, occupational accidents, unemployment, retirement and disability, and essential services directly provided to the individual, such as assistance for persons faced by personal challenges or crises (such as debt, unemployment, drug addiction or family breakdown), to ensure that the individuals are able to completely reintegrate into society (rehabilitation, language training for immigrants), and services concerning the labour market (occupational training and reintegration). These services include integration activities for individuals with long-term health or disability problems. Social housing is also included (ibid).

\section{MINIMUM LEVELS}

Minimum or basic levels of SGI involve the objectives of general interest and access for beneficiaries to the SGI products. Universal service and access are notions referred to repeatedly in the relevant policy documents which display the ambition and the political will that everybody in the Union should experience the same service level, regardless of territorial location.

Adding localisation theories as well as the functions of supply and demand to this equation makes the situation even more complicated. Various actors in a community (individual/enterprise/ organisation) have different needs, and as the basic level conceptualisation changes, the varied set of effects/functions and concepts such as thresholds, 'critical mass' and vulnerability applied at the local community and regional level mean that a certain range and level of SGI provision, varying across the territory, would be necessary for the proper functioning and development of different local communities and regions. Additionally, a minimum level could per se refer both to the types of services and to the acceptable level of each service necessary to guarantee universal access. Some services may not even be required by the direct user or beneficiary; rather their presence and operations may be important in a wider societal context thereby also affecting other people and businesses/activities (Foss 2011:22). What is needed to live a fulfilling life according to Articles 14, 34, 35, 36 of the EU Charter of Fundamental Rights, however, remains unclear.

\section{SHARED RESPONSIBILITY}

In the Treaty of Amsterdam the importance of SGEI is acknowledged, with the Treaty assigning the responsibility for the functioning of various services to the Community and to Member States 
"each within their respective powers" (European Commission 2003:4-5). In Article 16, responsibility is divided between the EU and the Member States to ensure the creation of appropriate policies to secure the provision of SGEI while Article 86(2) gives Member States the possibility to transfer the responsibility for SGEI provision to private enterprises. All producers and providers must obey competition rules but the Treaty acknowledges that, where conflicts arise, service provision is more important than the application of EU regulations (European Commission 2003:9).

Some SGI cannot be provided effectively by market forces alone due to various geographical and social circumstances; the market price may simply become too high for remote areas or for consumers with low purchasing power. Yet the Treaty states clearly that SGI should be offered to all citizens indiscriminatingly. If the market cannot satisfy the need for services, the public authorities become, by default, responsible for their provision, but the definition and scope of such services can be independently decided (European Commission 2004:4). One ongoing trend across the Union is the change in the nature of provision, from the public authorities themselves to public-private partnerships or fully private providers, monitored by public authorities (European Commission 2003:8). The Green Paper on SGI acknowledges the complexity of this situation, stating that the division between EU policies and national responsibility and governance systems can lead to problems and misunderstandings (European Commission 2003:9).

\section{METHODOLOGY AND MATERIAL}

This paper aims to produce a qualitative discourse analysis relying significantly on the official policy documents published by the EU. Additional information is taken from other relevant policy documents as well as from research reports and articles. The main empirical data used to support the discussion comes from five chosen key documents, namely: the Green and White Papers on Services of General Interest (European Commission 2003, 2004), the Communication of Social Services of General Interest (European Commission 2007), the Europe 2020 strategy (European Commission 2010b), and the Territorial Agenda (European Union 2011). The first three concern the concept of SGI, containing discussions on definition, categorisation and the legal framework. The latter two are strategic documents, describing the current contextual surroundings and the broader situation in respect of EU politics, its key targets and areas while, in addition, highlighting the policy attitudes, as well as various trends and developments.

The Fifth Report on Economic, Social and Territorial Cohesion (European Commission 2010a) is the most referenced document in this paper because of its broad scope and a thorough description of current developments in terms of policies and international differences, policy areas and their spatial dimensions. The Report covers many of policy areas where the EU plays a significant role, discussing them in a territorial perspective.

There are several other EU policy documents dealing with this issue. Under the Polish EU Presidency, a report on territorial keys was developed in which the SGI are discussed and framed as a key policy concept (Böhme et al. 2011). A subsequent scientific analysis of this effort was made by Zaucha et al. (2012). Alas, the policy documents produced in relation to the Polish EU Presidency cannot be given the same weight and importance as the policy documents produced by the European Commission. Hence, they are not included in this study. 


\section{A THEORETICAL FRAMEWORK}

\section{RIGHTS THEORY}

In the key SGI policy documents the notion of rights is mentioned repeatedly. Access to SGEI is, according to Article 36 of the Charter of Fundamental Rights (European Parliament 2000), a fundamental right for all EU citizens. The wording differs slightly across the key documents, from citizens and enterprises to persons, and the general catch-all 'everybody'. Indeed, several times the documents argue that SGI are a part of the EU citizens' fundamental rights, but how can a right be defined?

Rights are principles of freedom or entitlement, in other words, normative rules that can be based on legal, social or moral principles and stating what is or is not allowed to be done or owned. Rights Theory is normally divided into analytical and normative interpretations (Simmonds 1986). In this paper an analytical approach is adopted to investigate what a right is in relation to SGI. As a right is a value loaded moral concept its definition is framed by theories. Notable here are theories of interest and of choice. Interest theory argues that someone has a right when others have duties which protect one of that person's interests. The theory differentiates between failing to respect someone's rights and failing to fulfil an obligation which is not part of a right. According to interest theories, the obligation implied by a right is an obligation towards the right holder because it is the right-holder's interest which is protected by the right. Choice theory states that a person has a right when others have duties which protect one of that person's choices. According to choice theories, the obligation implied by a right is an obligation to the right-holder because it is the right-holder's choice which is protected by the right. A natural right is supposed to be derived from human nature or god, and is a kind of universal and non-specific social right. Active and passive rights describe someone's right to do or not to do something (Rainbolt 2006:3-4).

The relation to the beneficiary is another classification instrument. The most common are the basic right, privilege, power, and immunity. Right and privilege correspond here to the concepts of claim rights and liberty rights (Simmonds 1986:136). Rights are the basis of society functioning and are, therefore, closely related with politics, politics that develops policies and creates the basis of the societal system which, in turn, dictates normative rules and perceptions of what is right. In the correlation between rights and duties, the concept of rights is often used in politics, and they are interpreted as something good in themselves. But often rights are connected or correlated to duties (Simmonds 1986:139); a specific example of this in the discussion on SGI is the determination of the tax levels which is ultimately decisive for public spending levels.

\section{HUMAN RIGHTS}

The rights to SGI can be classified as human rights which are "commonly understood as inalienable fundamental rights to which a person is inherently entitled simply because she or he is a human being" (Sepúlveda et al. 2004:3). The modern discourse on human rights was initiated by the UN Declaration of Human Rights, adopted in 1948, in the aftermath of the Second World War, and which begins with the statement: "All human beings are born free and equal in dignity and rights. They are endowed with reason and conscience and should act towards one another in a spirit of brotherhood" (United Nations 1948, Article 1).

In the UN Convention on Human Rights it is stated that "rights and freedoms" shall be subject to the restrictions that are necessary for the general welfare. In documents describing the rights, exceptions like this, which could undermine the strength of the document as a whole, are common. At the same time, this approach can also be seen as a way of securing such rights for everyone. From 
a utilitarian point of view this means that individual rights only exist if they contribute to the general welfare (Simmonds 1986:150).

The development of human rights is commonly divided into three generations, each emphasising the watchwords from the French revolution - Liberty, Equality, Fraternity. Among the human rights, civil and political rights are separated from economic, social and cultural rights. The first generation consists of civil and political rights which protect the individual from the state; they include freedom of speech, the right to a fair trial, freedom of religion, voting rights etc. The secondgeneration human rights are fundamentally economic, social and cultural in nature. These rights secure citizens' right to equal and good conditions, and impose the duty to respect, promote and to fulfil upon the government, however, this depends on the availability of resources in a given state. The duty is imposed on the state because it controls its own resources. The right to SGEI in the EU Charter of Fundamental Rights belongs to this group. The third generation of rights goes further than individuals and citizens, and is expressed through, for example, documents of international law, including the 1972 Stockholm Declaration of the United Nations Conference on the Human Environment as well as the 1992 Rio Declaration on Environment and Development, etc., (Stanford Encyclopaedia of Philosophy 2010).

This division of human rights has been criticised, especially the second and third generation iterations. What if the state does not have the resources to fulfil the duties implied to its citizens? Another criticism is that the second- and third-generation human rights serve as an attempt to cloak political goals. The Nobel Laureate in economics F. A. Hayek has argued that the second generation concept of social justice cannot have any practical political meaning, stating that "no state of affairs as such is just or unjust (...) a spontaneously working market, where prices act as guides to action, cannot take account of what people in any sense need or deserve" (Hazlett, 1992:5).

\section{POLITICAL PHILOSOPHY}

When discussing what minimum levels of provision of SGI a society should have, John Rawls and his principles of distributive justice, provides a natural starting point. Rawls (1992) constructs two principles to achieve distributive justice. The first of these principles is the Liberty Principle, establishing equal basic liberties for all citizens. 'Basic' liberty entails the (familiar in the liberal tradition) freedoms of conscience, association, and expression as well as democratic rights; Rawls also includes in his set personal property right, but this is defended in terms of moral capacities and self-respect, rather than an appeal to a natural right of self-ownership. This stance, however, distinguishes Rawls' account from John Locke's classical liberalism and Robert Nozick's libertarianism.

Rawls argues that a second principle of equality would be agreed upon to guarantee liberties that represent meaningful options for all in society, and ensure distributive justice. For example, formal guarantees of political voice and freedom of assembly are of little real worth to those desperately poor and marginalised in society. Demanding that everyone have exactly the same effective opportunities in life would almost certainly offend the very liberties that are supposedly being equalised. Nonetheless, we would want to ensure at least the "fair worth" of our liberties: wherever one ends up in society, one wants life to be worth living, with enough effective freedom to pursue personal goals. Thus participants would be moved to affirm a two-part second principle comprising Fair Equality of Opportunity and the difference principle. This second principle ensures that those with comparable talents and motivation face roughly similar life chances and that inequality in society works to the benefit of the least advantaged (Malnes \& Midgaard 1993). 
Seen in the perspective of Services of General Interest the minimum provision of these services should be set at a level where the least advantaged in society benefit the most. This is, however, a relative threshold as the minimum level of provision e.g. may vary from SGI to SGI while geographical differences can also be expected.

Michael Walzer (1983) is usually identified as one of the leading proponents of the "communitarian" position in political theory. Communitarianism in philosophy can be defined by its response to the philosophy of Rawls (1992), and the criticism is mainly targeted at the image Rawls presents of humans as atomistic individuals. Communitarians claim that values and beliefs are formed in public space, in which debate takes place. Both linguistic and non-linguistic traditions are communicated to children and form the backdrop against which individuals formulate and understand beliefs. The dependence of the individual on community members is, however, typically understood as descriptive.

Central to the communitarian philosophy is the concept of positive rights, which are rights to or guarantees of certain things. These may include state subsidised education, state subsidised housing, safe and clean environment, universal health care, and even the right to a job with the concomitant obligation of the government or individuals to provide one. To this end, communitarians generally support social security programmes, public works programmes, and laws limiting such things as pollution.

A common objection is that by providing such rights, communitarians violate the negative rights of the citizens, the rights to not have something done to you. For example, taxation to pay for such programmes as described above relieves individuals of property. Proponents of positive rights, by attributing the protection of negative rights to the society rather than the government, respond that individuals would not have any rights in the absence of societies, a central tenet of communitarianism, and thus have a personal responsibility to give something back to it.

Communitarianism cannot be classified as being wholly left or right, and many theorists claim it represents a sort of radical centre. Progressives in the U.S. sense or social democrats in the European sense generally share the communitarian position on issues relating to the economy, such as the need for environmental protection and public education (Tidens idéserie 1989). A communitarian view of SGI would lead to government subsidies to improve the accessibility of these services. Improving the accessibility to make SGI affordable to a greater number of persons increases the positive freedom for those with limited means, regardless of where they live.

A contrary view is presented by Robert Nozick (1974). His book "Anarchy, State and Utopia” was written as a response to John Rawls (1971) egalitarianism. Nozick argues that a distribution of goods is just if brought about by free exchange among consenting adults and from a just starting position, even if large inequalities subsequently emerge in the process. Nozick appealed to the Kantian idea that people should be treated as ends (what he termed 'the separateness of persons'), not merely as a means to some other end. Nozick thus challenged the partial conclusion of John Rawls's Second Principle of Justice, in which social and economic inequalities are to be arranged in such a way that they are to be of greatest benefit to the least-advantaged members of society. Nozick suggested, as a critique of Rawls and utilitarianism, that the sanctity of life made the property rights non-negotiable, and that an individual's personal liberty made the state policies of redistribution illegitimate (Malnes \& Midgaard 1993). This principle has served as a foundation for many rightwing/libertarian arguments in modern politics.

In line with this libertarian reasoning, SGI should only be provided on the principle of free exchange. In other words, SGI should only be provided to those who can pay for them; if you cannot afford to pay for e.g. health care this SGI will not be provided to you. 
Friedrich Hayek is sometimes considered a liberal philosopher (Gray 1986), sometimes a conservative one (Nisbet 1986). Hayek ([1944]1993) displays some reservations about a free market system and laissez-faire capitalism, but the book remains, in essence, a warning against the dangers of central planning. In the book, Hayek writes that the government has a role to play in the economy through the monetary system, working-hours regulation, institutions for the flow of proper information, and other principles on which most members of a free society will tend to agree. He argues in favour of a society organised around a market order, in which the apparatus of state is employed almost (though not entirely) exclusively to enforce the legal order (consisting of abstract rules, and not particular commands) necessary for a market of free individuals to function. These ideas were informed by a moral philosophy derived from epistemological concerns regarding the inherent limits of human knowledge. Hayek argued that his ideal individualistic, free-market polity would be self-regulating to such a degree that it would be a society which does not depend for its functioning on finding good men to run it.

Hayek (1959) disapproved strongly of the notion of social justice. He compared the market to a game in which there is no point in calling the outcome just or unjust, and argued that social justice is an empty phrase with no determinable content; likewise, the results of the individual's efforts are necessarily unpredictable, and the question as to whether the resulting distribution of incomes is just has no meaning. He regarded any attempt by the government to redistribute income or capital as an unacceptable intrusion upon individual freedom: the principle of distributive justice, once introduced, would not be fulfilled until the whole of society was organised in accordance with it. This would produce a kind of society which in all essential respects would be the opposite of a free society (Malnes \& Midgaard 1993).

With regard to a safety net, Hayek's statements may be surprising to some of his followers today. He was prepared to tolerate some provision for those threatened by extreme indigence or starvation, be it only in the interest of those who require protection against acts of desperation on the part of the needy. Hayek (1959) saw no reason why the state should not help to organise a comprehensive system of social insurance, but such mandatory universal healthcare and unemployment insurance did not necessarily have to be directly provided by the state.

Based on Hayek's reasoning, a basic provision of SGI can be acceptable, but does not have to be ensured by the public sector. As a functioning market may not exist, it can be assumed that Hayek would support a basic public provision of SGI in peripheral and rural areas.

Utilitarianism is a theory in normative ethics holding that the proper course of action is the one that maximises overall "happiness". According to utilitarianism, the moral worth of an action is determined only by its outcome, although it is debatable how much consideration should be given to actual consequences, foreseen consequences, and intended consequences. Two influential contributors to this theory are Jeremy Bentham and John Stuart Mill (1987).

Mill develops a Principle of Utility which he believes can be proved. The principle of utility determines the rightness of acts (and/or of rules of action) by their effect on the total happiness. Unlike Bentham, Mill does not take happiness just as a mathematical sum of pleasures minus pains, differing only on quantitative measures like intensity and duration. Mill also includes the quality of the actions taken to promote happiness. Mill (1987) also notices a practical restriction to his principle of utility: people will not be motivated by the principle of utility unless they happen to care about promoting the total happiness (as very few people do).

A utilitarian approach can be applied to SGI. Depending on how general happiness is related to SGI, it can be increased by changes in the provision of SGI. 
Public choice theory makes use of modern economic tools to study problems that are traditionally in the province of political science. From the perspective of political science, it is the subset of positive political theory that models voters, politicians, and bureaucrats as mainly self-interested. Public choice theory studies such agents and their interactions in the social system either as such or under alternative constitutional rules. Public choice theory is intimately related to social choice theory. Two of the leading contributors to public choice theory are Gordon Tullock (1976) and James Buchanan (1988).

Public choice theory is often used to explain how political decision-making results in outcomes that conflict with the preferences of general public. For example, many advocacy groups and 'pork barrel' projects do not represent the wishes of society as a whole. Nevertheless, it often makes sense for politicians to support these projects. It may make them feel powerful and important. It can also benefit them financially by opening the door to future wealth as lobbyists. A given project may be of interest to the politician's local constituency, increasing the district votes or campaign contributions. Politicians generally pay little or nothing for gaining these benefits, as they are spending public money. Special-interest lobbyists are also behaving rationally. They can gain government favours worth millions for a relatively small initial investment. Moreover, they face the risk of losing out to their competitors if they do not seek these favours. The taxpayer is also behaving rationally. The cost of defeating any one government give-away is very high, while the benefits to the individual taxpayer are very small. Each citizen pays only a few pennies or a few dollars for any given government favour, while the costs of ending that favour would be many times higher. Everyone involved has rational incentives to do exactly what he/she is doing, even though the desire of the general constituency is the opposite of what is being proposed. Costs are diffused, while benefits are concentrated. The voices of vocal minorities with much to gain are heard over those of indifferent majorities with little to lose individually.

The minimum level of provision of SGI can, from a public choice perspective, be seen as the result of rent-seeking interest groups, politicians who want to get (re)elected, self-optimising bureaucrats, and voters. Changes in the minimum provision of SGI thus occur as a result of changed outcomes in the political game.

\section{LOCALISATION THEORIES}

Central place theory, developed in 1933 by a German geographer Walter Christaller who studied settlement patterns in southern Germany, explains the spatial distribution of settlements or services. The theory builds on a series of assumptions, such as a flat surface and evenly distributed population, and perfect competition in the economy. The theory covers the concepts of central place, low order, high order and sphere of influence. The crux of the theory is that a central place is a settlement which provides one or more services for the population living around it. Low order services are basic services while high order services are more specialised. The sphere of influence is the area under the influence of the central place. The two core concepts here are: the threshold which is the minimum population required to bring about the provision of certain goods or services and the range of goods or services which is the average maximum distance people will travel to purchase these goods and services. In combination, these two factors determine what services can be found on each level and, therefore, are ultimately decisive for the pattern of settlement. As transport costs are assumed to be the same in all directions, the form of theoretical settlement in perfect conditions is hexagonal in shape (Christaller 1933, Knowles \& Wareing 1976, Openshaw \& Veneris 2003). 
The concept of basic (low order) services in central place theory has common characteristics with the concept of basic levels of SGI. The basic concepts of threshold and range are applicable and could provide a theoretical contribution to the analysis of territorial patterns in the context of SGI. A key aspect for distribution is "need" which could be related to Christaller's threshold and range in the sense that there is a relationship between the maximum distance people are willing to travel to get a good or a service, and the fact that a minimum number of people is required as a basis for providing such goods and services (Foss 2011).

The relationship between these concepts indicates the difference between the necessities of life which require services that are supplied daily across the territory and more preference- or eventrelated requirements for which an uninterrupted daily supply is not necessarily required. This implies the need for a range of goods and services as found in central place theory. It is also important to bear in mind that the conceptual framework for what can be classified as low or high order services and needs develops and differs as the society does - in socio-economic, technical and cultural ways. As Olof Foss argues "( $t$ )he concept applies in two ways; i) a service(type)-specific minimum standard in relation to specified users/beneficiaries, and ii) a community/region or population-/business-group specific "minimum" standard for the general/aggregate range and level of services. A territorial "benchmark" approach will be employed in order to analyze the relative level of SGI in different types of territories and identify the (types of) areas with a particularly low basic level of services" (Foss 2011:24).

Central place theory predicts a special pattern of cities, but only in relation to very specific and unrealistic assumptions. Production costs and transportation costs may vary for many reasons, such as topography and access to natural resources to mention a few. The advantage of this theory is that it offers a reasonable description of the hierarchy of urban centres and the spatial pattern of urbanisation (Knowles \& Wareing 1976, Knox \& Marston 2004).

Agglomeration theory is a localisation theory that examines territorial specific concentrations of different kinds. Agglomeration can be defined as the concentration of something in a given area and states that many benefits can be derived from physical proximity, both direct and indirect (Johansson \& Quigley 2004:2). Clusters of businesses in the same or related branch, such as can be found in 'Silicon Valley', or even cities could be described as agglomerations, and both are the result of real or perceived benefits. The cluster concept is further developed by authors like Porter and Marshall (Karlsson 2008), and should not be confused with industrial symbiosis even though the two concepts explain the advantages of nearness. Cluster refers to the concentration of companies of the same kind which cooperate, while industrial symbiosis refers to the fact that different activities complement each other (one company's waste is another's raw material, etc). Commonly, industrial symbiosis "engages traditionally separate business in a collective approach to competitive advantage involving physical exchange of materials, energy, water and/or by-products. The keys to IS (industrial symbiosis) are collaboration and the synergistic possibilities offered by geographical proximity" (Van Berkel et al. 2008:1271).

As noted previously, cities and urban areas can be seen as agglomerations, and naturally a higher concentration of SGI can be found in densely populated areas. Consequently, the issues of access have different characteristics, depending on rural and urban characteristics of a given territory. Densely populated areas are affected by problems like crime, violence, vandalism, pollution and noise two to three times more severely than sparsely populated areas. Surveys of people living in cities, accordingly, show a high level of dissatisfaction with air quality and safety and, in several cases, they show low levels of trust (European Union 2010a:xvi). At the same time, urban areas are the drivers 
of growth and creativity, and thus they are important for the knowledge-based economy (European Union 2010a:xxix).

\section{A THEORETICAL SYNTHESIS}

The principles of entitlement and rights consist of normative rules and as such they are based upon social, legal and moral values on what is, for example, good or bad, right or wrong, excess or minimum provision. Notions of what is a just distribution of a good or service, or a fair distribution, are necessarily subject to ideologically based debate, same as the issue whether the current or desired distribution is optimal in terms of the freedom and choice of individuals and enterprises.

The overview presented here thus indicates that the extent to which access to SGI can per se be considered a human right is debatable. The discussion has also shown the impact that various strands of political philosophy, i.e. political ideologies, have had on what an acceptable minimum provision of SGI is actually deemed to be. The same can be concluded for enterprises. Localisation theories in general, and central place theory in particular, offer a much more scientific approach to what services can individuals and enterprises expect, depending on their geographical location. Hence these theories do not set a threshold for the minimum provision of SGI.

As the right to SGI is a highly politically charged term, we cannot expect to find in the policy documents reviewed any precise definitions of what rights individuals and enterprises have to SGI. Nor will we find well-defined thresholds for minimum provision.

\section{FUNDAMENTAL RIGHTS IN KEY POLICY DOCUMENTS}

The point of departure for the analysis is that citizens and enterprises have rights to SGI (European Commission 2004). Furthermore, ongoing developments in the economic and organisational construction of service provision (e.g. liberalisation, public-private partnerships etc.,) make the division between SGEI and SGI (including SSGI) vague, blurred and fuzzy. The analysis here aims, therefore, to differentiate between individuals and enterprises and, by examining the actual wording and tone of the key policy documents, to filter out what rights to SGI individuals and enterprises have.

\section{THE GREEN PAPER ON SGI}

In the Commission Green Paper on SGI, rights in respect of SGI are mentioned repeatedly, and the term used to describe beneficiaries is citizens in reference to the Charter of Fundamental Rights. More generally, the document speaks of users and consumers without any further definition. Initially, the document states that the role of SGIs "is essential for increasing quality of life for all citizens and for overcoming social exclusion and isolation. Given their weight in the economy and their importance for the production of other goods and services, the efficiency and quality of these services is a factor for competitiveness and greater cohesion, in particular in terms of attracting investment in less-favoured regions" (European Commission 2003:3). Even though neither enterprises nor businesses are mentioned in the statement, the focus on the economy and production implies not only the importance of SGI, even for the business community, but also the fact they do not enjoy equal rights. A spatial dimension is also stressed. The Paper states that the efficient provision of SGI is a basic condition for the functioning of the Single Market. The text subsequently notes that the Charter of Fundamental Rights only refers to services of general economic interest. Furthermore, the document continues that the concept of universal service guarantees "access for everyone, whatever the economic, social or geographical situation, to a service of a specified quality at an affordable price" (European Commission 2003:4). Here the beneficiary is everybody and the concept of universal 
access further highlights the spatial dimension. This more general approach now predominates, and on page 6 the term all persons is introduced and used; later in the document the terms users and consumers are used. The user-concept could, however, also be interpreted as including enterprises.

The existence and provision of SGI are acknowledged to be of significant economic and social importance, and therefore specific measures have been adopted in sectoral Community legislation "to address the specific concerns and needs of consumers and businesses, including their right to have access to high-quality international services" (European Commission 2003:18). Thus it seems that businesses can also be the holders of rights to SGI too.

Other than promoting universal access and the demand that everybody should be guaranteed good quality, affordable services, the Green Paper neither discusses nor even mentions any minimum levels. The closest comparable label used here is socially acceptable levels in terms of the obligations to provide a public service and of the quality being the rationale for service provision, and thus the subject of regulation. Moreover, in the conceptual discussion on SGI, universal service is identified as a common element in defining services of general/economic interest. The concept of "universal service refers to a set of general interest requirements ensuring that certain services are made available at a specified quality to all consumers and users throughout the territory of a Member State, independently of geographical location, and, in the light of specific national conditions, at an affordable price" (European Commission 2003:16). This specified quality could be interpreted in line with the political will to develop a minimum level of provision. The notion of universal service was developed for network services but the Green Paper widens the concept to include all SG(E)I. Notwithstanding the above, the notion of universal service is meant to be regularly adjusted to the evolving needs. Yet another reference to minimum levels is made in the context of the element of continuity that is required for some services.

In the section discussing the quality of services the paper states that " $(t)$ he Community did not rely on market forces alone to maintain and develop the quality of services. In some cases, quality standards are defined in Community legislation. They include, for instance, safety regulations, the correctness and transparency of billing, territorial coverage, and protection against disconnection. In other cases, Member States are authorised or required to set quality standards" (European Commission 2003:38).

\section{THE WHITE PAPER ON SGI}

Compared to the Green Paper, the White Paper clearly and unequivocally ascribes businesses as well as individuals with rights and needs in respect of SGI. The exact wording is that there is a need "to ensure the provision of high-quality and affordable services of general interest to all citizens and enterprises in the European Union" (European Commission 2004:4) The Paper continues: "citizens and businesses rightly expect to have access to affordable high-quality services of general interest throughout the European Union. For the citizens of the Union, this access is an essential component of European citizenship and necessary in order to allow them to fully enjoy their fundamental rights. For enterprises, the availability of high-quality services of general interest is an indispensable prerequisite for a competitive business environment" (European Commission 2004:4). Moreover, the term citizen is changed to consumer and provision in respect of enterprises and their consumers is depicted as a strategic driver in relation to attaining many of the EUs main goals and "to becom[ing] the most competitive and dynamic knowledge-based economy in the world capable of sustainable economic growth with more and better jobs and greater social cohesion" (European Commission 2004:4-5). This combination of citizens and enterprises recurs throughout the text; regarding the 
spatial dimensions of access across the EU territory promoting social and territorial cohesion, the access for both citizens and enterprises is seen as essential. Indeed, one of the most important issues here is to ensure consumer and user rights, and in this context the Paper states that this is equally important for "all groups of the population" (European Commission 2004:9).

The White Paper does not, however, discuss or indeed even mention minimum levels of services. Access throughout the territory is argued to be important in promoting social and territorial cohesion while the concept of universal service is promoted as a crucial element in the debate on SGI. The Commission also agrees that all citizens and users should be provided with services of general interest of a high quality (European Commission 2004:8).

\section{A COMMISSION COMMUNICATION ON SGI, INCLUDING SGI}

In the Communication it is stated that Services of General Interest, including those of social nature, are of fundamental importance for the daily life of citizens and enterprises, and they reflect the European model of society (European Commission 2007:3). The fact that SGEI is a fundamental right is stressed but in the Communication the terms citizens, consumer and user are used interchangeably. In the Communication it is argued that user rights should be specified and upheld.

Regarding minimum levels, no direct statement is made but the Communication suggests that "where an EU sector specific rule is based on the concept of universal service, it should establish the right of everyone to access certain services considered as essential and impose obligations on service providers to offer defined services according to specified conditions, including complete territorial coverage and at an affordable price" (European Commission 2007:10). Here the beneficiary is the general everyone. Further down the same page, the issue of upholding user rights is discusses and it is stated that the citizens', consumer and user rights should be promoted while continuing to address both consumers and users. Achieving high quality levels as well as ensuring safety and affordability is also described as important.

Universal service provides for a minimum set of rights and obligations which can, as a general rule, be further developed at the national level. According to the Communication, universal service is a dynamic concept, which needs to be updated regularly sector by sector. Promoting access throughout the territory of the Union is essential to enhance territorial cohesion in the EU, as noted previously in the case of social services. Territories with a geographical or natural handicap, such as outermost regions, islands, mountains, sparsely populated areas and external borders, often face challenges in terms of access to services of general interest, due to their remoteness from major markets or the increased cost of connection. These specific needs must be taken into account.

\section{EUROPE 2020}

In the Europe 2020 strategy the notion of 'rights' for either individuals or enterprises is not mentioned in any way nor is the issue of minimum levels referenced (European Commission 2010b). Nevertheless, several interesting observations can still be made. The strategy contains qualitative but not binding targets that are proposed to be translated by Member States into national targets and trajectories. These targets are closely related to SGI distribution and provision. Moreover, the document is the only one considered here which discusses quantitative levels and which could, therefore, be incorporated into a discussion of minimum levels. A target level could easily be translated to a minimum level, and the way these targets are proposed, as crucial but non-binding, implies the difficulties that quantitative levels have for implementation in a large and heterogeneous context that is the EU. In addition, the EU's structural weaknesses in the light of current financial crisis are 
identified here as lower growth rates, lower employment levels, and fewer worked hours on average then its main economic competitors.

The Commission is proposing five measurable targets in the strategy for smart, sustainable and inclusive growth. (1) The employment rate for the population between 20 and 64 years of age should be at least $75 \%$, compared to the 2010 rate of $69 \%$. This should be achieved by improving the involvement of women, older workers and migrants. A functioning labour market and labour market mechanisms in themselves also constitute a service of general interest. In addition, there is also a strong connection between employment and SGI as SGI providers are large employers; this is especially true in more remote areas. (2) Further work to reach the EU target of investing 3\% of GNP in research and development, especially by improving the conditions for private investment. The current target will be kept and an indicator that will reflect R\&D and innovation intensity will be developed. Research and development strategies are closely related to the knowledge-based economy and by extension to education, life-long learning and other SGI, such as telecommunications. (3) Climate and energy are increasingly important issues, and efforts to achieve the "20/20/20" target should be redoubled. This means reducing greenhouse gas emissions by at least $20 \%$ compared to 1990 levels or by $30 \%$ if the conditions are right. The share of renewable energy sources in energy consumption should be increased to $20 \%$, and a $20 \%$ increase in energy efficiency should also be achieved. Goals for climate and energy involve many SGI, especially the energy sector itself but also transportation infrastructure, water and waste management, etc. (4) The education target aims at reducing the dropout from early education from $15 \%$ in 2010 to $10 \%$. An additional target here is to increase the share of 30-34-year-olds with a tertiary education from $31 \%$ to at least $40 \%$. (5) To reduce poverty by reducing the numbers below national poverty lines by $25 \%$. The goals concerning education and poverty have an SGI connection through access and quality of services.

\section{THE TERRITORIAL AGENDA}

Similarly to the 'Europe 2020' strategy document, the Territorial Agenda does not explicitly mention rights or minimum levels in relation to SGI. The document does, however, claim to be the territorial dimension of the Europe 2020 strategy. Views and visions about SGI and territorial cohesion are discussed and the aspects of accessibility and 'even and fair distribution' are the key areas here. The Territorial Agenda states that exclusion from the socio-economic circuit has a strong territorial character and the risk of exclusion is higher in areas with low accessibility, weak economic performance, lack of social opportunities or other particular territorial circumstances. Fair and affordable accessibility to services of general interest, information, knowledge and mobility are seen as essential for territorial cohesion. The Agenda argues that providing services and minimising infrastructure barriers can improve competitiveness and promote sustainable and harmonious territorial development of the European Union. Among other things, it is therefore important to secure access to road, rail, water-based and air transport, as well as other infrastructure facilities, such as broadband and trans-European energy networks (European Union 2011).

The Territorial Agenda states that to enhance territorial cohesion it is necessary to effectively coordinate policies and create territorial knowledge and share it.. The responsibility and capacity for implementation lies with the EU institutions, Member States, regional and local authorities and private actors. This multi-level governance is important in effectively managing the different functional territories and the responsibilities of local, regional, national and European actors in compliance with the principle of subsidiarity (European Union 2011:9). Furthermore, the Agenda argues for the importance of reaching the targets presented in the Europe 2020 strategy which can 
further be seen as an argument for interpreting the levels as proposed minimum levels in respect of the SGI concerned. The Territorial Agenda also places a strong emphasis on private enterprises, especially small and medium-sized ones, confirming their importance and consequently their right to expect support services, e.g. SGI.

\section{DISCUSSION}

SGI have a crucial role to play in society with the scope of action as well as the needs constantly affected by external drivers and developments. Megatrends, like globalisation and macro-economic shifts as well as changing technology and demographics are interlinked with the usage and development of SGI, both conceptually and in terms of daily usage. The focus on spatial dimensions has gained importance since the introduction of territorial cohesion as one of the EU's three main cohesion goals. Together with economic and social cohesion the Territorial Agenda strengthens the cohesion policy of the EU by promoting even development across all regions and by seeking to reduce differences. Harmonious development is also promoted in the growth model of the 'Europe 2020' strategy which aims for increasing competitiveness, expanding employment, improving social inclusion and protecting and enhancing the environment in every region. The political emphasis placed on the need for a multi-level governance system also helps to make the EU more visible to its citizens (European Union 2010a:XXXII).

There is no official definition of territorial cohesion but according to the Green Paper the " (...) concept of territorial cohesion builds bridges between economic effectiveness, social cohesion and ecological balance, putting sustainable development at the heart of policy design" (European Commission 2008:3). This suggests that territorial cohesion is designed to ensure harmonious and sustainable development. It acknowledges territorial capital and the fostering of local growth potential and natural resources while in addition acknowledging the importance of geographical context, governance structures and service provision.

Many territorial perspectives exist in respect of SGI. The general interest objective mainly focus on the SGI "service" products and their potential direct target groups and intended functions. An additional view is to focus on the external effects of SGI produced and provided in a region, e.g. importance of SGI in employment, and other general socio-economic and welfare effects. Figures extracted from CEEP (2010) and the European Parliament (2005) show that the SGI sector employs almost one third of the total EU labour force and the sector also contributes a considerable share of national GDP. These two effects must, therefore, be considered when assessing territorial aspects (Foss 2011:22).

\section{ECONOMIC TRENDS}

Despite the increasing involvement of private actors (who are also affected by the financial crisis), many of services of general interest rely heavily on state financing. Public expenditure and public investment in the public sector tends to be larger in the Member States with the highest levels of GDP per capita, especially when it comes to social protection. In 2008, the total public expenditure in the EU amounted to 47\% of GDP and it rose to almost 51\% in 2009 (European Commission 2010a:147). Recent studies have shown a correlation between government spending and economic activity with the conclusion that public investment increases the rate of return on private capital and strengthens economic growth. The institutional capacity to maximising these positive effects is also important in this context (European Commission 2010a:151). Decentralisation has also, over time, led to a shift 
in responsibility for public expenditure from central to lower levels of government. The shift has not, however, been followed by a proportional increase in resources. Public spending at the sub-national levels of government in the EU accounted for around $28 \%$ of the total spending in 2009, though with large differences across Member States (ibid).

The EU economy is highly dependent on its ability to export, but as the financial crisis turns into a general economic downturn worldwide, it will become increasingly difficult for the EU to export its way out of recession. This has made policy makers rather nervous and responses have, according to the CEEP Macro Economic Dialogue, been both insufficient and too slow. Compromises have been made between what is economically necessary and what is politically acceptable (CEEP 2011). One obvious risk in the current situation undoubtedly relates to the declining level of public service provision and to the likelihood of further public sectors cuts, which could potentially affect growth potentials as well as impact social cohesion. In a recent study by Humer and Palma (2013), a strong link between the GDP per capita level and the SGI provision is emphasised. Their findings suggest that countries with a high GDP per capita generally have a better provision of SGI, i.e. GDP per capita is a factor enhancing SGI provision.

The commission promotes the view that more public services could be financed and/or provided by private actors. However, this is not an alternative without risks. It is often argued by its opponents that financing and transaction costs would be higher, that budgeting in this way would increase risks, and that this kind of societal change should be driven by political decision and not by short-term and opportunistic fiscal response (CEEP 2011).

\section{POPULATION CHANGES}

The European Union is currently facing significant demographic change. Life expectancy is among the highest in the world and combined with low birth rates will result in a rising median age of the population, an increasing share of the older population, and thus a decreasing percentage share of the working age population. This will have a significant impact on both social services and labour politics. The Europe 2020 strategy accounts for this situation in its stated targets: lifelong learning, and retaining older persons in the workforce. Nevertheless, huge differences remain within the EU, in particular on the regional scale. The regional dimension is especially important when it comes to access to services, especially healthcare. (European Commission 2010a:79-80)

The population structure is affected by migration. Within the EU, there is an ongoing migration trend from central and eastern regions, but the flows have been reduced in the current economic crisis, and in some areas reverse migration has occurred. In some areas, there are distinct geographic shifts - in the Nordic countries from north to south, and in Germany from east to west (European Commission 2010a:84-87).

\section{A NEW REALITY}

The development of new telecommunications services undoubtedly affects the society and is a major driver of economic development, alone currently accounting for 5\% of EU GDP. Even though there are huge differences in the level of coverage and adaptation on both national and, in particular, the regional level, the development of ITC is one of key elements in the rise of the knowledge-based economy. The target for 2020 is for all Europeans to have access to an internet connection with speeds of $30 \mathrm{Mbps}$ or more, and for at least $50 \%$ of European households to have access to internet connections above $100 \mathrm{Mbps}$ (European Commission 2010a:186). 
Issues relating to environmental degradation, biodiversity loss and the unsustainable use of natural resources, as well as predicted new migration trends, all call for novel and robust policy responses. Mitigation efforts in respect of improving energy efficiency, reducing greenhouse gas emissions and developing adaption strategies have become increasingly important, and they influence policy design in many areas. The predicted effects of climate change have a clear spatial dimension as some areas are more vulnerable and will be harder hit than others. The most severe impacts are predicted to affect the southern and eastern regions of the EU and sectors like tourism and agriculture in particular (European Commission 2010a:143). A potentially positive effect would be a boost to GDP growth due to the increased need for green investment (European Commission 2010a:118). The increasing focus on climate will also affect physical structures and thus the need for environmental capacity such as that relating to green infrastructure and ecosystem services (European Commission 2010a).

\section{INDIVIDUALS VERSUS ENTERPRISES}

The notion of rights is used repeatedly in this paper, referring both to rights theory and the specific wording in policy documents. In the policy documents, the concept is never defined and little or no connection exists between the way the wording is used and a discussion of the conceptual basis for rights. As these rights often refer to legal documents, most significantly the Fundamental Charter, the citizens' right to SGI can be seen as an institutional right. On the other hand, the idea that everybody should have the same opportunities and the same level of care is also based in moral values, which constitute the basis for non-institutional rights. In many cases rights are connected to duties, in the case of SGI many societal services are dependent on the taxation of which citizens are duty-bound to pay. The right to SGI can also be interpreted as a human right, and in the division of human rights SGI belongs to the second generation of rights, namely those framed as economic, social and cultural rights. This division has, however, been criticised. What if the state in question does not have sufficient funds to make such services available? Should not the market be responsible for these kinds of services? When it comes to differentiating between individuals and enterprises in relation to the question of their right to SGI, the situation is both crystal clear and extremely blurry. According to the Fundamental Charters, the citizens of the EU have the right to SGEI. But an ongoing development in the context of evolvement of private actors in service provision and of liberalisation makes the boundaries increasingly murky. As seen in the key policy documents, there is no stringent use of wording, and according to the documents citizens, persons, enterprises, consumers, users, businesses and everybody all have rights to SGI as well as fair and non-discriminatory access to SGI. The strategy documents in particular, however, maintain a strong focus on enterprises.

\section{SHOULD LOCALISATION MATTER?}

In Central Place Theory, spatial distribution is explained using a hierarchy of services, lower and higher order, and the concepts of Threshold - the minimum population required for a certain service or good, and Range - the maximum distance people are willing to travel to get a service or good. Even though the theory is dependent on a series of assumptions and is criticised for presenting an unrealistic and simplified reality, it is still viewed as highly influential and as a reasonable description of the spatial pattern and of the urban/rural hierarchy. In an attempt to further apply this reasoning in respect of the territorial dimensions of SGI, an obvious conclusion would be that everybody simply cannot expect to enjoy the same level of access. Following the arguments presented by Olaf Foss (2011), the basic (lower order) service beneficiaries could include communities which would still represent the maximum distance the population would be willing to travel to enjoy a specific service, 
and at the same time, the size of the community would decide which services could be offered locally. According to the current legislative picture outlined above, Member States have the right to affect these market structures, with the need to ensure basic provision often being seen as more important than competition rules, thus making it possible for states to subsidise service distributers in remote areas. This is of course an important tool to have for being able to fulfil the fundamental rights of all EU citizens but these issues should be handled carefully. The right to have access to a good service level is not the same as having the right to the same service level, simply because of the heterogeneous reality that the EU Member States and regions are facing.

Returning to localisation theories, the existence of cities can partially be explained by the notion of agglomeration, and the concentration of functions by cluster theories and/or industrial symbiosis. As noted previously, these concentrations, e.g. cities, have different conditions, experience and needs than those of rural areas. At the same time, the goal of territorial cohesion is to secure equal opportunities for all, no matter their localisation. The concept supports a harmonious development of the Union but its elements, i.e. territorial efficiency, quality and identity, account for local differences, arguing that these should be seen as strengths.

A reoccurring refrain in the paper is that SGI evolve as the society evolves, a development driven by many factors and external drivers, including economic development and changes in demography and migration, the rise of new technologies, etc. Globalisation is a megatrend affecting all parts of society, and the development and usage of telecommunications changes the way we perceive distances. At the same time, an area where this development is lagging behind creates a digital divide. The spatial dimension does not disappear, it just changes. As stated in the Fifth Report on Social, Economic and Territorial Cohesion "(s)patial proximity continues to matter. (...). Nevertheless, access to global pipelines of knowledge generation and knowledge exploitation remain important for all types of region, as innovation processes are increasingly open, global, multi-disciplinary and multi-actor" (European Commission 2010a:53).

\section{MINIMUM LEVELS - BUT WHAT IS REQUIRED?}

None of the key documents makes a direct reference to the notion of minimum levels of SGI though many interesting findings have been made. The right to high quality, affordable services is stressed as is the notion of 'socially acceptable' levels of provision. Universal service is referred to as a general interest requirement and is, according to the Green Paper, supposed to ensure a specific level of quality. The White Paper offers a similar reasoning and connects the notion of general access to the goals of cohesion. The same kind of argumentation can be found in the Communication on Social Services. The two strategy documents 'Europe 2020' and 'Territorial Agenda 2020' refer to the quantitative targets presented in Europe 2020. These levels are non-binding but are, nevertheless, supposed to be translated into national targets and trajectories, and are the only qualitative levels found in the policy documents. These could, however, be interpreted as minimum levels, and should they be attained, it would mean that they represent the minimum level to be expected in terms of service provision.

The thresholds in respect of the minimum provision of a certain SGI can thus easily be manipulated. Ringen (1987) argues that a country with the lowest threshold of a minimum provision of welfare will have a lower share of e.g. poor relative to a country with a high threshold. When the threshold is changed, also accessibility, availability, affordability, quality and choice change. This reasoning can be transferred to a wider set of services, labelled as SGI. If the threshold on the maximum distance pupils have to travel to primary school before they are entitled to a seat on a school bus is doubled, 
a larger share of pupils will live within the threshold, compared to the previous figure. This is an example of the Ringen's Paradox, named after its founder, Steinar Ringen (1987).

In order to discuss the introduction of additional minimum levels to current EU levels of service production, many issues would have first to be resolved. If pressure was brought to bear on equalising SGI service provision levels this would conflict with the principle of subsidiarity, as Member States themselves define SGI. Moreover, current developments in the SGI sectors have been characterised by liberalisation and by an increasing evolvement of private actors, a development that can change the juridical framework for these services. This is, however, far from being uncontroversial. The PUSEMOR (2007) study shows that local actors in rural and remote areas desire minimum levels to be decided, so they can effectively know what they can demand. On the other hand, the consultation presented in the White Paper shows something of a consensus in that the European Union should not be given any additional power in this regard.

\section{CONCLUSION}

Access to SGI is seen as a fundamental right for all EU citizens, but in the key policy documents, enterprises and businesses are also mentioned in connection with these rights' statements. Rights are complex and are defined with reference to political goals as well as to ideology and moral values. Issues concerning the implementation of service levels are not mentioned in the key EU policy documents. What is a minimum level? Should the quantitative levels or the quality of service be the main measurement criteria? On which governance level? And for whom? As long as these questions remain unanswered, scientific clarity on the rights of individuals or enterprises to minimum levels of service provision, will remain elusive.

\section{REFERENCES}

Buchanan J.M., 1988. Maktens gränser. Stockholm: Timbro.

Böhme K., Doucet P., Komornicki, T., Zaucha J., Swiatek D., 2011. How to Strengthen the Territorial Dimension of 'EUROPE 2020' and EU Cohesion Policy. Warsaw.

Ceep 2011. Note for the Macroeconomic Dialogue Meeting on September 20th, 2011. www.ceep.eu [1 April 2013].

Christaller W., 1933. Die zentralen Orte in Süddeutschland. Jena. Gustav Fischer.

European Commission, 2003. Green paper on services of general interest COM(2003)270.

European Commission, 2004. White paper on Services of general interest. COM(2004)374 .

European Commission, 2006. Implementing the Community Lisbon programme: Social services of general interest in the European Union. COM(2006)177 Final.

European Commission, 2007. Services of general interest, including social services of general interest: a new European commitment. COM(2007)725 Final.

European Commission, 2008. Green Paper on Territorial Cohesion. Turning territorial diversity into strength. COM(2008)616 Final.

European Commission, 2010a. Investing in Europe's Future. The Fifth Report on Economic, Social and Territorial Cohesion. Luxembourg: Publications Office of the European Union.

European Commission, 2010b. Europe 2020. COM(2010)2020 Final. 
European Union, 2011. The Territorial Agenda of the European Union 2020. Agreed at the Informal Ministerial Meeting of Ministers responsible for Spatial Planning and Territorial Development on 19th May 2011 Gödöllő, Hungary.

European Union, 2012. Waste Management. http://europa.eu/legislation_summaries/environment/ waste_management/index_en.htm [1 April 2013].

European Parliament, 2000. Charter of Fundamental Rights in the European Union. 2000/C 364/01 [1 April 2013].

European Parliament, 2005. Services Directive: directions for use, European Parliament News.

Foss O., 2011. Appendix 1 Concepts and definitions of Services of General Interest, [in:] D. RAUHUT, L. BORGES (eds.) Indicators and Perspectives for Services of General Interest in Territorial Cohesion and Development. Luxembourg: ESPON.

Gray J., 1986. Liberalism. University of Minnesota Press.

Hazlett T.W., 1992. The Road from Serfdom: Foreseeing the Fall. Retrieved from http://www.reason. com/news/show/33304.html [1 April 2013].

Hayek F.A., 1959. The Constitution of Liberty. University of Chicago Press.

Hayek F.A., 1993 [1944]. The Road to Serfdom. Routledge.

Humer A., Palma P., 2013. The Provision of Services of General Interest in Europe: Regional Indices and Types Explained by Socio-economic and Territorial Conditions. EUROPE XXI, vol 23, pp. 85-104.

Johansson B., Qiugley J.M., 2004. Agglomeration and networks in spatial economies. Papers in Regional Science, vol. 83, pp. 165-176.

Karlsson C., 2008. Handbook of Research on Cluster Theory. Edward Elgar Publishing Limited. Cheltenham.

Knowles R., Wareing J., 1976. Economic and Social Geography. London: Heinemann.

Knox P.L., Marston S.A., 2004. Human Geography. New Jersey: Pearson Education Inc.

Pusemor, 2007. Public Services in Sparsely Populated Mountain Areas. Final Report of the Interreg III B project.

Malnes R., Midgaard K., 1993. De politiska idéernas historia. Lund: Studentlitteratur.

Mill J.S., Bentham J., 1987. Utilitarianism and other essays. Penguin Classics.

Nisbet R., 1986. Conservatism. Open University Press.

Nozick R., 1974. Anarchy, State and Utopia. Basic Books.

Openshaw S., Veneris Y., 2003. Numerical experiments with central place theory and spatial interaction modelling. Environment and Planning A Vol. 35 No. 8, pp. 1389-1403.

Rawls J., 1992. A Theory of Justice. Oxford University Press.

Rainbolt G.W., 2006. Rights Theory. Philosophy Compass Vol. 1 No. 1, pp. 11-21.

Ringen S., 1987. The Possibility of Politics: A Study in the Political Economy of the Welfare State. Oxford: Clarendon Press.

Sepúlveda M., Van Banning T., GUDMUNDSDÓTTIR, G., CHAMOUN, C., Van Genugten, W.J.M., 2004. Human rights reference handbook. Ciudad Colon, Costa Rica: University of Peace.

Simmonds N.E., 1986. Juridiska principfrågor, rättvisa, gällande rätt och rättigheter. Stockholm: Norstedts.

Stanford Encyclopedia Of Philosophy, 2010. Human Rights. Retrieved at: http://plato.stanford.edu/ entries/rights-human/ [1 April 2013].

Tidens Idéserie 1989. Michael Walzer., [in:] Idéer om rättvisa. Tidens idéserie vol. 1. Tidens förlag.

Tullock G., 1976. The Vote Motive. The Institute of Economic Affairs. 
United Nations, 1948. The Universal Declaration of Human Rights.

Van Berkel R., Fujita T., Hashimoto S., Fujii, M., 2008. Quantitative Assessment of Urban and Industrial Symbiosis in Kawasaki, Japan. Environmental Science Technology, vol. 43, no. 5, pp. 1271-1281.

Van De Walle S., 2008. What services are public? What aspects of performance are to be ranked? The case of "services of general interest". International Public Management Journal Vol. 11 No. 3, pp. 256-274.

Walzer M., 1983. Spheres of Justice. Basic Books.

Zaucha J., Komornicki T., Böhme K., Światek D., Żuber, P., 2012. Territorial Keys for Bringing Closer the Territorial Agenda of the EU and the Cohesion Policy. European Planning Studies, DOI:10.1080/09654313.2012.722976., pp. 1-22. 